\title{
Inhibition of photosynthesis in phytoplankton by the submicron size fraction concentrated from seawater
}

\author{
Curtis A. Suttle
}

Marine Science Institute, The University of Texas at Austin, PO Box 1267, Port Aransas, Texas 78373-1267, USA

\begin{abstract}
Ultrafiltration was used to concentrate the 2-200 nm size fraction from seawater samples 100 - to 1000 -fold. Electron microscopy indicated that these concentrates were heavily enriched with virus-like particles. When aliquots from these concentrates were added to natural seawater samples, primary productivity $\left({ }^{14} \mathrm{C}\right.$-bicarbonate uptake) was either little affected or suppressed within minutes by up to $78 \%$. In some instances as little as a $20 \%$ increase in the concentration of the $2-200 \mathrm{~nm}$ size fraction in seawater reduced relative carbon fixation rates by nearly $50 \%$. Autoclaving the concentrates before addition reduced or eliminated the bioactive effect. Larger additions caused greater inhibition, although a point was reached where further additions of concentrate did not result in greater photosynthetic suppression, relative to samples to which autoclaved concentrate was added. Microautoradiography indicated that there were fewer photosynthetically-active cells in seawater samples to which untreated concentrates were added, when compared to samples receiving autoclaved concentrate. Phytoplankton $>3 \mu \mathrm{m}$ were affected the most. This indicated that specific organisms were affected as opposed to photosynthesis being reduced throughout the community. In vivo chlorophyll fluorescence paralleled changes in carbon incorporation, and increased most slowly when the greatest additions of concentrate were made. Nonetheless, growth of phytoplankton recovered several days after the concentrates were added, suggesting either that some cells were unaffected by the addition or that resistance to the bioactive agent(s) developed over time. The data provide further evidence for the presence of a strongly bioactive component that inhibits primary productivity, which is associated with the virus-rich 2-200 nm size fraction of seawater.
\end{abstract}

\section{INTRODUCTION}

It is now well established that high concentrations of virus-like particles are a ubiquitous feature of marine waters (Torrella \& Morita 1979, Bergh et al. 1989, Proctor \& Fuhrman 1990, Hara et al. 1991, Paul et al. 1991) and apparently of freshwater systems as well (Klut \& Stockner 1990). These natural viral communities can be extremely dynamic (Bratbak et al. 1990, Heldal \& Bratbak 1991), and data suggest that they may cause significant mortality in natural marine bacterial and cyanobacterial communities (Proctor \& Fuhrman 1990, Heldal \& Bratbak 1991). Yet, despite the abundance of virus-like particles in seawater, much remains to be learned about the impact of viruses on planktonic communities.

Based on observations that large numbers of viruslike particles could be recovered from seawater using ultrafiltration (Proctor et al. 1988, Proctor \& Fuhrman
1990) we used similar methodology in a successful attempt to isolate from seawater pathogens that infected marine phytoplankton (Suttle et al. 1990, 1991a). As pathogens infecting a number of important groups of phytoplankton were present in the ultrafiltration retentate (2-200 nm size fraction), an aliquot of this relatively high molecular weight concentrate was added to a seawater sample to determine if photosynthesis (uptake of ${ }^{14} \mathrm{C}$-bicarbonate) was inhibited. Surprisingly, a $6 \%(\mathrm{v} / \mathrm{v})$ addition of concentrate to a natural seawater sample reduced the rate of ${ }^{14} \mathrm{C}$ incorporation by $46 \%$. Based on this observation a series of experiments was initiated to examine the relationship between the volume of concentrate added to seawater and the degree of inhibition of photosynthesis. These results demonstrated that addition of this bioactive material to natural seawater samples could reduce rates of primary productivity.

These observations coupled with the recent interest in 'dissolved' organic carbon in the sea (e.g. Benner et al. 
1992, Martin \& Fitzwater 1992, Ogawa \& Ogura 1992) and observations of high concentrations of viruses in coastal and offshore waters, prompted further investigation into the effects of material concentrated from the 2-200 $\mathrm{nm}$ size fraction of seawater on photosynthetic rates of the phytoplankton. This paper presents additional data on the bioactive nature of material concentrated from seawater in the $2-200 \mathrm{~nm}$ size fraction.

\section{MATERIALS AND METHODS}

Concentration of the $2-200 \mathrm{~nm}$ size fraction from seawater. Surface seawater samples (50 to 100 l) were collected either from the pier or the entrance to the small-boat harbor at the University of Texas Marine Science Institute (USA), and dispensed into acid-washed and insed polyethylene carboys. Aliquots of this water were gently poured into a 20 I stainless-steel vessel and pressure filtered (<130 $\mathrm{mm} \mathrm{Hg}$ ) through $142 \mathrm{~mm}$ diameter glass-fiber (MFS GC50, $1.2 \mu \mathrm{m}$ nominal pore size) and low protein-binding Millipore GVWP 'Durapore' membrane filters $(0.22 \mu \mathrm{m}$ pore size) to remove zooplankton, phytoplankton and most bacteria. Filters were connected in series and held in place by stainless-steel filter holders. A peristaltic pump and spiral-wound ultrafiltration cartridge $(30000 \mathrm{MW}, \mathrm{Amicon} \mathrm{S} 1 \mathrm{Y} 30)$ was used to concentrate the $2-200 \mathrm{~nm}$ size fraction ca 100 - to 1000 -fold (assuming $30000 \mathrm{MW}$ is equivalent to $2 \mathrm{~nm}$ ), based on the final volume of the concentrate. Further details of the method are described in Suttle et al. (1991a).

Microscopy. Virus-like particles (VLPs) in the concentrates were observed using a JOEL JEM-1000X transmission electron microscope (TEM), Carboncoated 400 mesh copper grids were floated on a drop of concentrate for $20 \mathrm{~min}$, rinsed through a series of distilled water drops to remove the sait and negativestained for $10 \mathrm{~s}$ with $1 \% \mathrm{w} / \mathrm{v}$ uranyl acetate.

The abundance of viral particles in the concentrates were estimated by staining samples with a fluorochrome (DAPI, 4,6 diamidino-2-phenylindole) specific for double-stranded DNA (dsDNA), and enumerating the stained particles with an epifluorescence microscope. This method likely underestimates virus numbers as non-dsDNA viruses and some small dsDNA viruses cannot be visualized using DAPI (Suttle unpubl.). The microscopy methods are described in detail elsewhere (Suttle 1992).

Photosynthetic rates. The $2-200 \mathrm{~nm}$ size fraction was concentrated from seawater as described above and split into 2 portions, one of which was autoclaved at $121^{\circ} \mathrm{C}$ for 20 min. These concentrates were added back at a range of dilutions to 40 to $60 \mathrm{ml}$ of seawater collected at the same location from which the viral size fraction was concentrated. The samples were labelled with $5 \mu \mathrm{Ci}$ of ${ }^{14} \mathrm{C}$-bicarbonate and incubated either in darkness or under daylight fluorescent bulbs at an irradiance of $120 \mu \mathrm{mol} \mathrm{m} \mathrm{m}^{-2} \mathrm{~s}^{-1}$. Each experiment included autoclaved and untreated concentrates added at a range of dilutions, as well as controls receiving no addition. Treatments and controls were in duplicate. Immediately following the addition of the label and at 4 and $8 \mathrm{~h}$ afterwards aliquots of the samples were filtered onto $0.2 \mu \mathrm{m}$ pore size Poretics polycarbonate filters underlain with glass-fiber filters (Suttle et al. 1991b). Filters were placed in open scintillation vials in an airtight container and fumed overnight in the presence of an open bottle of concentrated $\mathrm{HCl}$. The container was then opened in a fume hood, the bottle of $\mathrm{HCl}$ capped, and the moisture in the vials allowed to evaporate. Scintillation fluor was added to the vials and the radioactivity retained by the filters determined using a Beckman LS 5801 scintillation counter.

Fluorescence measurements. In vivo chlorophyll fluorescence measurements were initiated in conjunction with one of the primary productivity experiments. After the seawater was filtered through $120 \mu \mathrm{m}$ pore size Nitex screening to remove the large zooplankton, $100 \mathrm{ml}$ was dispensed into each of four $125 \mathrm{ml}$ borosilicate flasks. Nothing was added to two of the flasks and $10 \mathrm{ml}$ of concentrate collected the previous day was added to the others. This was equivalent to a final concentration factor of 86.6. Fluorescence was monitored using a Turner Designs (Model 10) fluorometer at predetermined time intervals for $7 \mathrm{~d}$ following the addition of the concentrate. As well, at the end of the concurrent primary productivity experiment, samples for in vivo fluorescence were collected from each of the treatment and control samples.

Microautoradiography. Microautoradiography was used to determine the number of photosyntheticallyactive cells in treated and untreated seawater samples. No attempt was made to use autoradiography to quantify the radioactivity incorporated by individual cells. Samples for microdutoradiography were collected from seawater receiving no addition (control), or a $7.4 \%(\mathrm{v} / \mathrm{v})$ inoculum (concentration factor: 69$)$ of autoclaved or unautoclaved material concentrated from the viral size fraction. Incubations were carried out as outlined above for the photosynthetic rate experiments except that $32 \mu \mathrm{Ci}$ of ${ }^{14} \mathrm{C}$-bicarbonate was added to each of the bottles from which subsamples for microautoradiography were obtained. At the end of the $8 \mathrm{~h}$ incubation, $5 \mathrm{ml}$ samples were filtered under gentle vacuum onto the shiny sides of $25 \mathrm{~mm}$ diameter, $0.2 \mu \mathrm{m}$ pore size filters. Immediately after filtration the polycarbonate filters and underlays were transferred into a light-tight slide box. Shortly afterwards the filters were placed sample side down onto 
the surface of a glass slide which had been coated with autoradiographic emulsion. After drying at $4{ }^{\circ} \mathrm{C}$ overnight the filters were carefully peeled away from the dried emulsion in total darkness, and the slides exposed for $4 \mathrm{wk}$ at $4^{\circ} \mathrm{C}$ before development. The relatively high level of radioactivity used and the long exposure times for the autoradiograms minimized the possibility that photosynthetically-active cells would not be detected.

At $1000 \times$ magnification a minimum of 20 random fields were examined and 200 labelled cells of each size class counted. The 3 size classes $(<3,3-10$ and $>10 \mu \mathrm{m}$ ) were based on the maximum cell dimension.

\section{RESULTS}

\section{Rates of inorganic C uptake}

Ultrafiltration of seawater which was prefiltered through glass-fiber and $0.22 \mu \mathrm{m}$ pore size membrane filters resulted in concentration of the viral size fraction. The number of viruses in these concentrates was ca $10^{9} \mathrm{ml}^{-1}$ based on counts of DAPI-positive particles. TEM revealed that this material was very enriched with a diverse community of virus-like particles and was virtually free of bacteria or other recognizable particulate material (Fig. 1)

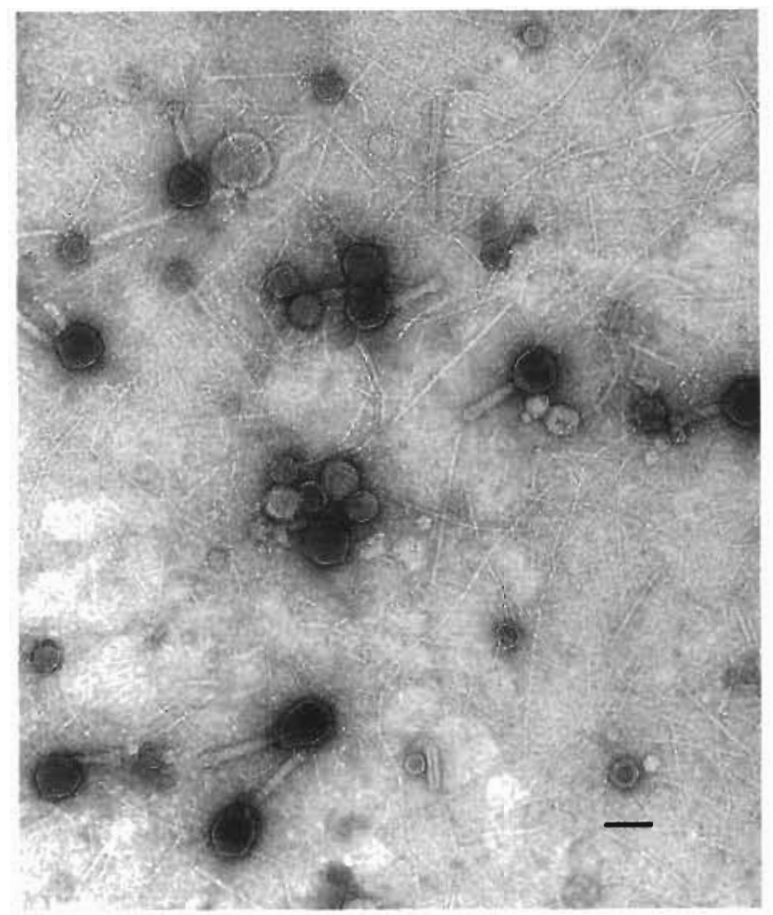

Fig. 1. Electron micrograph of a coastal natural marine viral community concentrated from seawater using ultrafiltration. Notice the great morphological diversity of the virus-like particles. Scale bar $=100 \mathrm{~nm}$
Addition of these concentrates to seawater samples typically resulted in inhibition of rates of photosynthesis, relative to samples which received either autoclaved concentrates or no addition (i.e. concentration factor 1) (Fig. 2A, B, D), although occasionally there was little or no inhibition of photosynthetic rates in response to the addition of concentrate (Fig. 2C). Autoclaving removed the effect of the inhibitory material; however, in some samples the largest additions caused reduced photosynthetic rates relative to the no-addition controls (Fig. $2 \mathrm{~A}, \mathrm{D})$. The decreases in photosynthetic rates occurred within minutes of the addition of concentrate and remained unchanged over a $2 \mathrm{~h}$ incubation (Fig. 3). Addition of ultrafiltrate to seawater samples did not affect photosynthetic rates (data not shown), indicating that the biological activity was not the result of a water soluble toxin resulting from the concentration procedure.

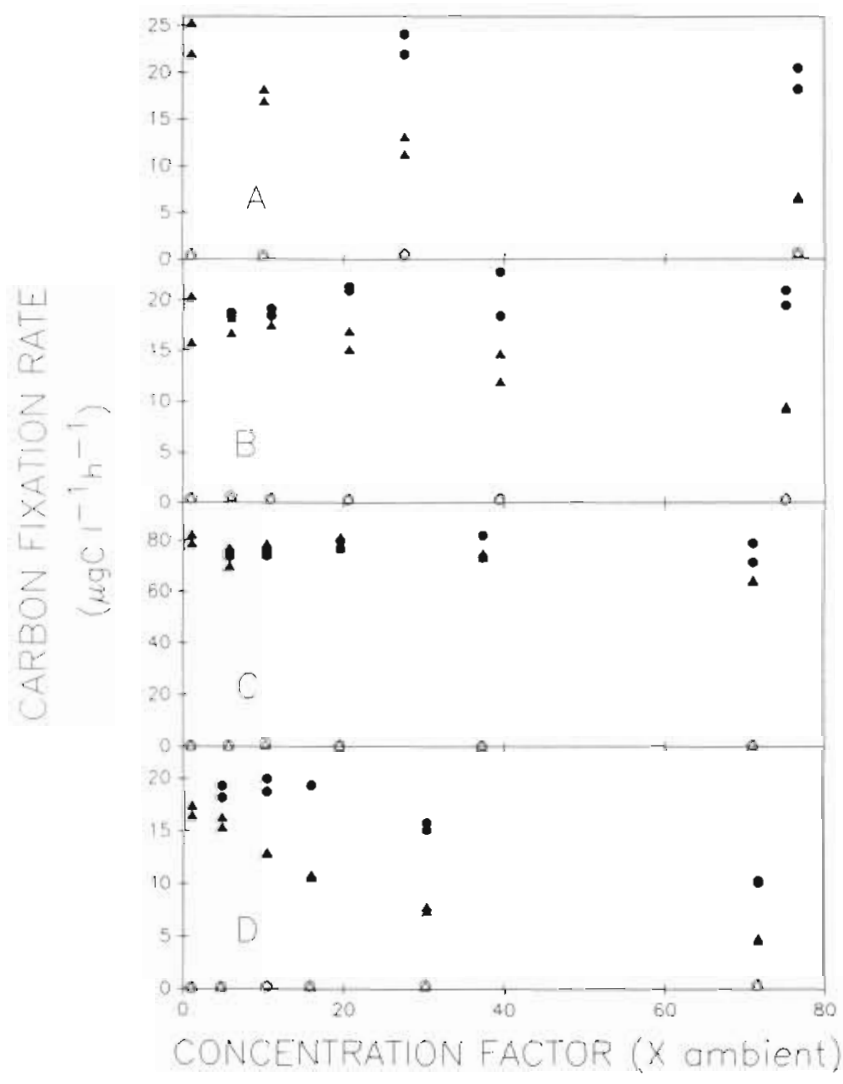

Fig. 2. Results of experiments conducted on (A) 14 and (B) 26 September 1989, and (C) 15 March and (D) 5 April 1990. High molecular weight material concentrated from seawater by ultrafiltration was added to seawater and rates of primary productivity measured during $4 \mathrm{~h}$ incubations. Closed symbols represent duplicate samples that were incubated in the light and to which either autoclaved ( ) or non-autoclaved ( $\mathbf{\Delta}$ ) concentrates were added. Open symbols represent samples that were incubated in the dark and to which either autoclaved $(0)$ or non-autoclaved $(\Delta)$ concentrates were added. The concentration factors assume that the $>30000 \mathrm{MW}$ fraction was concentrated with $100 \%$ efficiency 


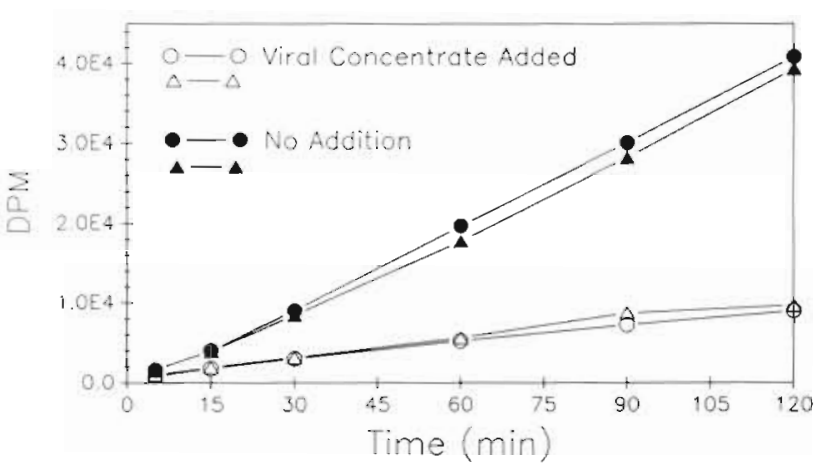

Fig. 3. Time course of accumulation of ${ }^{14} \mathrm{C}$-bicarbonate into phytoplankton in natural seawater and in natural seawater to which high molecular weight concentrate $(2-200 \mathrm{~nm}$ size fraction) had been added. Different symbols indicate data collected from duplicate treatments

Further, the $\mathrm{pH}$ of the retentate was the same as that of the seawater from which it was concentrated.

Moreover, the degree of photosynthetic suppression in response to the addition of concentrate was similar whether measured over 4 or $8 \mathrm{~h}$ (Fig. 4). As well, photosynthesis was never completely inhibited. A point was reached where further addition of concentrate did not result in greater photosynthetic suppression, relative to samples to which autoclaved concentrate had been added (Fig. 4)

Photosynthetically-active cells were easily recognized using microautoradiography (Fig. 5). These data were collected in conjunction with the experiments of 5 April 1990 (i.e. Figs, 2D \& 4D). In all 3 size classes the concentration of photosynthetically-active cells was lower in seawater samples exposed to concentrate than in samples receiving autoclaved concentrate (Fig. 6). In the $<3 \mu \mathrm{m}$ size fraction about $60 \%$ as many cells were associated with exposed silver grains in samples inoculated with concentrate as compared to those samples that received autoclaved concentrate ( $t$-test, $p=0.014)$. However, cells in the $<3 \mu \mathrm{m}$ size class appeared to be inhibited by the addition of autoclaved concentrate relative to cells which received no addition, although the difference was not significant ( $t$-test, $p=0.052)$. The results were even more striking for larger cells. In the $3-10 \mu \mathrm{m}$ size fraction the number of photosynthetically-active cells was reduced by about $90 \%$ in seawater samples exposed to concentrate, relative to samples receiving autoclaved concentrate ( $t$-test, $p=0.0002$ ). Similar results were observed for the $>10 \mu \mathrm{m}$ size fraction, although the number of photosynthetically-active phytoplankton was only reduced by about $70 \%(t$-test, $\mathrm{p}=0.023)$.

\section{In vivo chlorophyll fluorescence}

Temporal changes in fluorescence were consistent with phytoplankton growing at a lower rate in seawater samples to which concentrate had been added (Fig. 7). Values of in vivo fluorescence remained similar in control and treated seawater samples for $4.5 \mathrm{~h}$ following the addition of concentrate. Subsequently, the values diverged so that by $23 \mathrm{~h}$ the fluorescence in the samples to which concentrate was added was less than half that of samples which received no addition. After about $36 \mathrm{~h}$ the fluorescence began to increase in the seawater samples to which concentrate had been added, eventually surpassing that in the control cultures. This indicated that some cells were capable of growth in the presence of the concentrate.

The in vivo chlorophyll fluorescence of seawater samples was affected by the volume of concentrate added in much the same way as rates of photo-

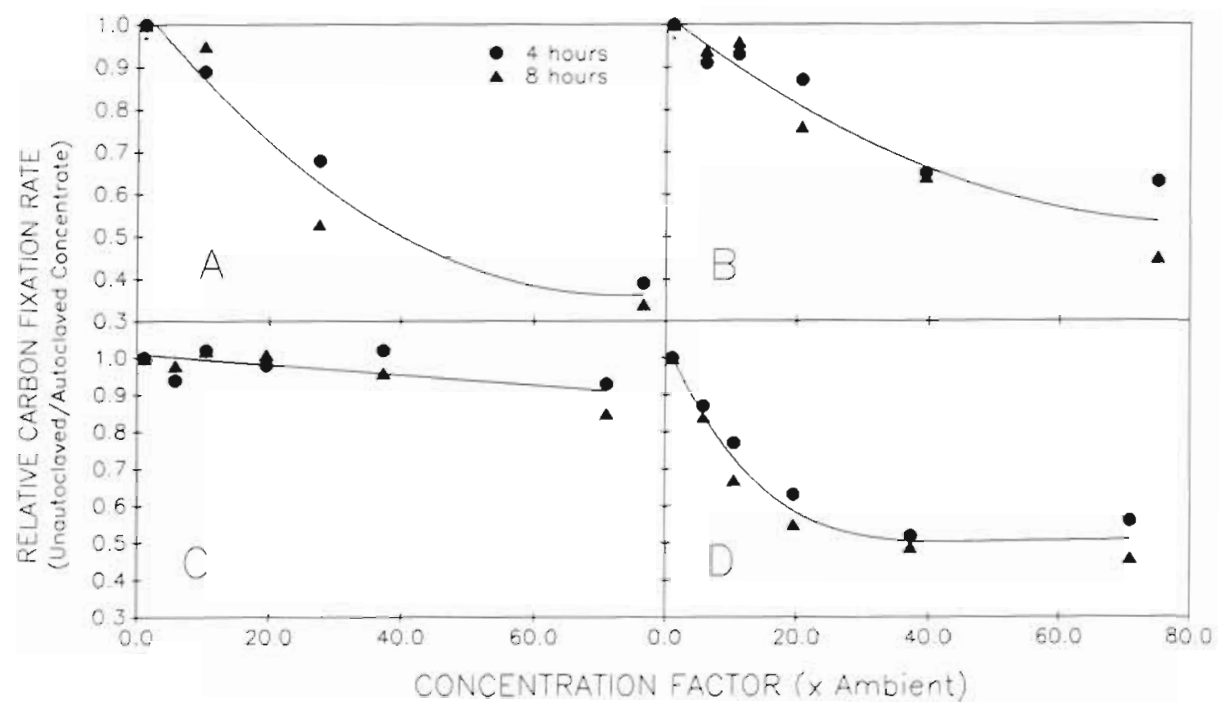

Fig. 4. Changes in photosynthetic rates in seawater to which 30000 MW ultrafiltration retentate has been added, relative to seawater to which autoclaved retentate was added, after $(\bullet / \mathrm{h}$ and (4) $8 \mathrm{~h}$. Curves were fitted by non-linear, least-squares regression analysis. Dates of experiments as in Fig. 2 


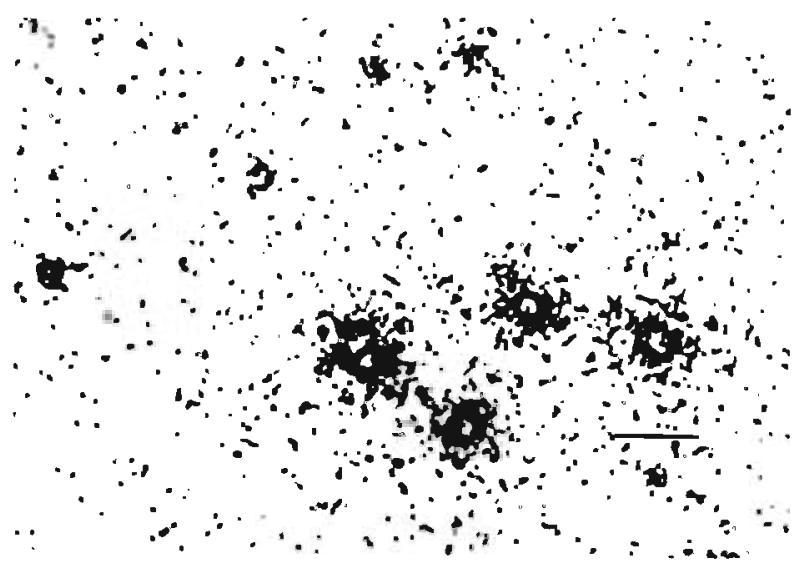

Fig. 5. Microautoradiograms showing 5 photosyntheticallyactive cells in the $<3 \mu \mathrm{m}$ size fraction (primarily Synechococcus spp.). Scale bar $=3 \mu \mathrm{m}$

synthesis were affected (Fig. 8). After $9 \mathrm{~h}$ of incubation samples exposed to untreated concentrate had lower levels of fluorescence than samples to which autoclaved concentrate had been added. Just as in the productivity experiments, a point was reached where further increases in the amount of concentrate added did not result in further decreases in fluorescence. Increases in the concentrate beyond a factor of about 10 times ambient resulted in fluorescence values that were about $60 \%$ of those to which the same quantity of autoclaved concentrate had been added.

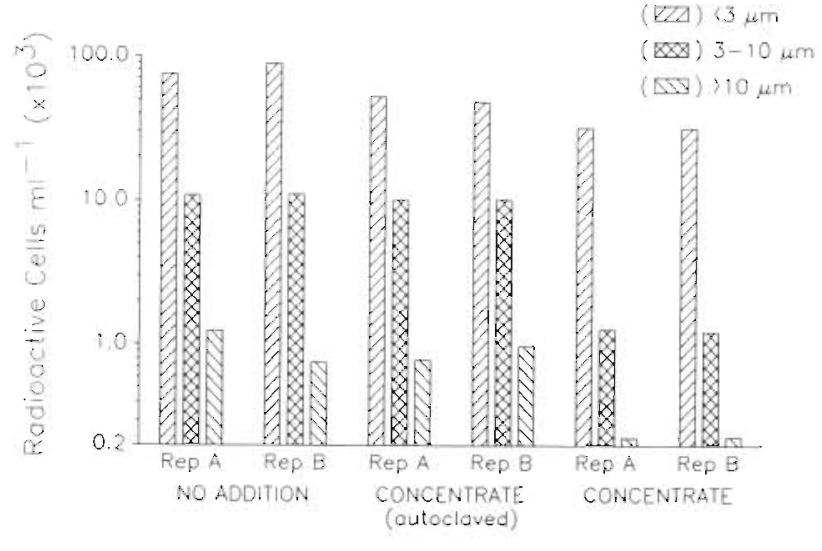

Fig. 6. Concentration of radioactively-labelled phytoplankton cells in natural seawater and natural seawater to which either autoclaved or untreated concentrate had been added. Experiments were in duplicate (Rep A and Rep B). The $<3 \mu \mathrm{m}$ cells consisted of Synechococcus spp. while the larger cells were made up of diatoms and larger flagellates

\section{DISCUSSION}

\section{Photosynthetic rates}

These data clearly demonstrate that one or more substances can be concentrated from the $2-200 \mathrm{~nm}$ size fraction of seawater that strongly inhibit rates of photosynthesis in natural communities of marine phytoplankton. Bacterial growth rates have also been observed to decrease when virus-enriched material, concentrated from seawater by ultrafiltration, has been added back to seawater samples (Proctor et al. 1988). The degree to which photosynthesis was affected by the addition of the concentrates varied between seawater samples. At times little or no inhibition was observed, whereas on other occasions rates were substantially reduced (Figs. $2 \& 4$ ). There were at least 2 bioactive components to the substance One component was heat labile and often caused strong reductions in photosynthetic rates when added at relatively modest enrichments. The other component remained bioactive after autoclaving, and was most effective at higher concentration factors. Consequently, even though rates of photosynthesis continued to decrease at concentration factors above 40 (Fig. 2), these decreases occurred whether or not the concentrate had been autoclaved, indicating that the effect was due to nonheat-labile components. The fluorescence data corroborated the productivity data
Fig. 7 In vivo chlorophyll fluorescence in natural seawater and seawater which was amended by adding a $9 \%$ inoculum of $30000 \mathrm{MW}$ concentrate. Each point is the mean value from duplicate cultures. SD's were less than the width of the symbols 


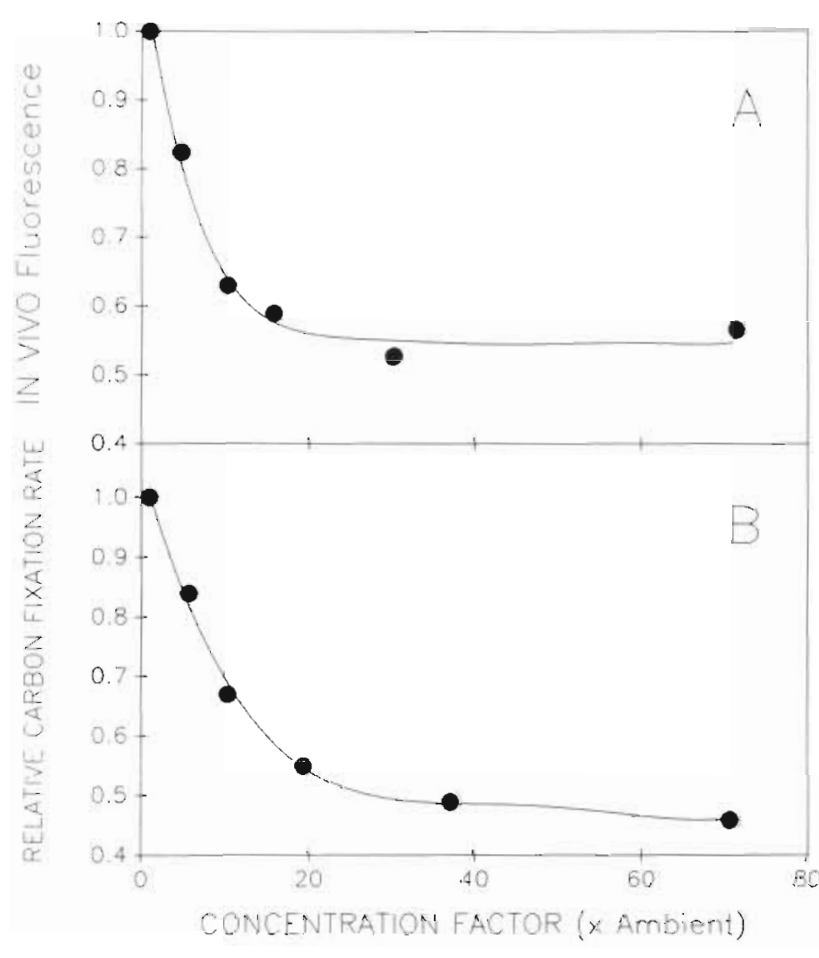

Fig. 8. (A) In vivo chlorophyll fluorescence and (B) carbon-fixation rate in natural seawater to which concentrate had been added, relative to seawater to which autoclaved concentrate was added. Data were collected ca $8 \mathrm{~h}$ after the addition of the concentrate

and showed that after a several hour lag in both treatments, growth rates were higher in samples to which concentrate was not added (Fig. 7).

There are 2 interpretations to the observation that photosynthetic rates decreased after addition of the concentrates. One is that carbon fixation was inhibited throughout the phytoplankton community. The other is that photosynthesis was suppressed in certain members of the community while other components were unaffected. Two aspects of the data suggest that the decreases in productivity resulted from selective inhibition of a subset of the phytoplankton community. First, the relative decrease in photosynthetic rates was less at higher concentration factors, suggesting that some cells were unaffected by the bioactive material. If the entire community were affected one would expect photosynthetic rates to continue to decline as the concentration factor increased. Second, after ca $36 \mathrm{~h}$, fluorescence began to increase in the samples to which concentrate had been added, suggesting that a subset of the phytoplankton community was growing.

Autoradiography showed that cells in the $>3$ and $>10 \mu \mathrm{m}$ size fractions (diatoms and flagellates) were very sensitive to the addition of the concentrate; whereas, cells in the $<3 \mu \mathrm{m}$ size fraction (largely
Synechococcus spp.) were much less so (Fig. 6). As the addition of untreated concentrate resulted in fewer cells with incorporated isotope, relative to samples to which autoclaved concentrate was added, it indicated that only certain cells were affected by the addition. If the entire assemblage were affected there should have been no difference in the concentration of photosynthetically-active cells (i.e. those associated with exposed silver grains) in seawater samples receiving autoclaved or untreated concentrate (although phytoplankton in the treatment samples would photosynthesize at a reduced rate). Given the strong grain development observed (Fig. 5), even cells with reduced photosynthetic rates should have been detected. Furthermore, in hundreds of experiments where $>30000 \mathrm{MW}$ concentrates were added to unialgal cultures of phytoplankton (e.g. Suttle et al. 1990, 1991a), growth rates were not reduced relative to controls receiving no addition, unless a pathogen for the particular alga being screened was present. Thus primary productivity, fluorescence, and microautoradiography data were all consistent with the hypothesis that carbon fixation was only suppressed in a subset of the phytoplankton community.

It is worth emphasizing that modest increases in the concentration factor caused substantial decreases in photosynthetic rates (Figs. $2 \& 3$ ). For example, as little as a 20 -fold increase in the concentration factor caused nearly a $50 \%$ decrease in relative carbon fixation rates in some instances (Fig. 4A, D). This assumes that the $>30000 \mathrm{MW}$ fraction was concentrated with $100 \%$ efficiency. If concentration efficiencies were lower this would indicate that the retentate was even more potent. It is conceivable that the bioactive substance was formed as part of the ultrafiltration procedure. Although this possibility cannot be easily dismissed there is no evidence of which I am aware indicating that bioactive substances can be formed when seawater is ultrafiltered.

Relative changes in fluorescence were similar to those observed for photosynthetic rates (Fig. 8). This was because growth rates were lower in seawater samples to which concentrate was added; therefore, fluorescence also increased more slowly. It was not because fluorescence decreased when concentrates were added (e.g. Fig. 7).

\section{Nature of the bioactive agents}

Transmission electron microscopy indicated that the material concentrated from $0.2 \mu \mathrm{m}$ filtered seawater was highly enriched in virus-like particles, with no other recognizable particulate material being visible (Fig 1). This confirms previous reports that both 
natural viral communities (Proctor \& Fuhrman 1990, Suttle et al. 1990, 1991a, Paul et al. 1991) and specific types of viruses (e.g. Belfort et al. 1974, 1976) can be concentrated efficiently from seawater by ultrafiltration

The heat-labile nature of the bioactive material also suggests that a biologically-mediated process was responsible for the decreases in photosynthetic rate. There are few candidates other than viruses that are strongly bioactive, fall in the 2-200 nm size range and are heat labile. The small molecular size of antibiotics (e.g. Austin 1989) and marine humics (900 to $1200 \mathrm{MW}$; Harvey \& Boran 1985) makes it unlikely that either is the active agent; further, humic acids are refractory by definition and should be relatively stable during autoclaving. Nonetheless, the possibility remains that free proteins or perhaps certain large heat-sensitive humic or fulvic acids or colloids could be responsible for suppressing primary productivity.

As photosynthetic rates were affected in a subset of the phytoplankton community it suggests that taxonspecific pathogens might be involved. The reason that the number of photosynthetically-active cells in the $<3 \mu \mathrm{m}$ size class was not as greatly affected may be that cyanophage-infected Synechococcus spp. photoassimilate carbon until the point of cell lysis, many hours later (Mackenzie \& Hazelkorn 1972). If viral pathogens were not the responsible agent it would imply that the bioactive substance specifically inhibits eukaryotes.

The fact that carbon assimilation was reduced within minutes of adding the concentrates to seawater and continued at the same reduced rate for hours afterwards (Fig. 4) does not refute the possibility that viruses caused the reduction of photosynthetic rates. Intuitively, one would expect viral infection to cause a gradual reduction in primary production as more cells became infected and as cellular processes began to be affected; however, this is not the case for all unicellular algae. Although data are limited, in some Chlorellalike algae carbon fixation is suppressed almost immediately following infection (Van Etten et al. 1983); whereas in Micromonas pusilla carbon fixation rates do not decrease until about $4 \mathrm{~h}$ post infection (Waters \& Chan 1982). It remains to be seen which, if either, will turn out to be typical for marine phytoplankton.

The fact that the bioactive component could not always be eliminated entirely by autoclaving implies that viruses were not the only agent responsible for reducing primary productivity. It was not possible to completely remove the inhibitory material by centrifugation of a concentrate at $114000 \times g$ for $150 \mathrm{~min}$ (data not shown). Therefore, some of the bioactive substance had a sedimentation coefficient of $<98$, less than that of even the smallest viral particles.
Initial observations of decreased productivity of marine bacteria (Proctor et al. 1988) and phytoplankton (Suttle et al. 1990) have been associated with the addition of concentrated natural marine viral communities to seawater. Even though viruses are essentially the only particles visible in these concentrates using TEM, other less heat-labile substances which also have the potential to inhibit primary productivity must be present as well. The present challengers are to determine how much of the photosynthetic suppression is the result of viral infection and how much is attributable to other high molecular weight bioactive substances. Ultimately, the goal must be determine the degree to which primary productivity is affected by these substances when they are present at ambient concentrations

Acknowledgements. A. M. Chan and F. Chen greatly assisted in the microautoradiography experiments and $\mathrm{M}$. T. Cottrell collected the fluorescence data. Comments of anonymous reviewers improved the manuscript. The research outlined in this proposal was supported by the National Science Foundation (OCE-9018833) and the Office of Naval Research (N00014-90-J-1280). Contribution No. 840 of the Marine Science Institute, The University of Texas at Austin.

\section{IITERATURE CITED}

Austin, B. (1989). Novel pharmaceutical compounds from marine bacteria. J. appl. Bact. 67: 461-470

Belfort, G., Rotem, Y., Katzenelson, E. (1974). Virus concentration using hollow fiber membranes. Water Res. 9: 79-85

Belfort, G., Rotem, Y., Katzenelson, E. (1976). Virus concentration using hollow fiber membranes - II. Water Res. 10: 279-284

Benner, R., Pakulski, J. D., McCarthy, M., Hedges, J. I., Hetcher, P. G. (1992). Bulk chemical characteristics of dissolved organic matter in the ocean. Science 255: 1561-1564

Bergh, O., Borsheim, K. Y., Bratbak, G., Heldal, M. (1989). High abundance of viruses found in aquatic environments. Nature, Lond. 340:467-468

Bratbak, G., Heldal, M., Norland, S., Thingstad, T F. (1990). Viruses as partners in spring bloom microbial trophodynamics. Appl. environ. Microbiol. 56: 353-366

Hara, S., Terauchi, K., Koike, I. (1991). Abundance of viruses in marine waters: assessment by epifluorescence and transmission electron microscopy. Appl. environ. Microbiol. 57: 2731-2734

Harvey, G. R., Boran, D. A. (1985). Geochemistry of humic substances in seawater. In: Aiken, G. R., McKnight, D. M., Wershaw, R. L. (eds.) Humic substances in soil, sediment and water. Wiley, New York, p. 233-247

Heldal, M., Bratbak, G. (1991). Production and decay of viruses in aquatic environments. Mar. Ecol. Prog. Ser. 72 : $205-212$

Klut, M. E., Stockner, J. G. (1990). Virus-like particles in an ultra-oligotrophic lake on Vancouver Island, British Columbia. Can. J. Fish. Aquat. Sci. 47: 725-730

Mackenzie, J. J., Hazelkorn, R. (1972). Photosynthesis and development of a blue-green algal virus SM-1. Virology 49: $517-521$ 
Martin, J. H., Fitzwater, S. E. (1992). Dissolved organic carbon in the Atlantic, Southern and Pacific oceans. Nature, Lond. 356: $699-700$

Ogawa, H., Ogura, N. (1992). Comparison of two methods for measuring dissolved organic carbon in seawater Nature. Lond. 356: 696-698

Paul, J. H., Jiang, S. C., Rose, J. B. (1991). Concentration of viruses and dissolved DNA from aquatic environments by vortex flow filtration. Appl. environ. Microbiol. 57: 2197-2204

Proctor, L. M. Fuhrman, J. A. (1990). Viral mortality of marine bacteria and cyanobacteria. Nature, Lond. 343: 60-62

Proctor, L. M., Fuhrman, J. A., Ledbetter, M. C. (1988). Marine bacteriophages and bacterial mortality. Eos 69: 1111-1112

Suttle, C. A. (1992). Enumeration and isolation of viruses. In Kemp, P. F., Sherr, B. F., Sherr, E. B., Cole, J. J. (eds.) Current methods in aquatic microbiology. Lewis Publ., Boca Raton, in press

Suttle, C. A., Chan, A. M., Cottrell, M. T (1990). Infection of phytoplankton by viruses and reduction of primary pro-

This article was presented by N. S. Fisher, Stony Brook, New York, USA ductivity. Nature, Lond. 347:467-469

Suttle, C. A., Chan, A. M., Cottrell, M. T. (1991a). Use of ultrafiltration to isolate viruses from seawater which are pathogens of marine phytoplankton. Appl environ. Microbiol. 57: 721-726

Suttle, C. A., Chan, A. M., Fuhrman, J. A. (1991b). Dissolved free amino acids in the Sargasso Sea: uptake and respiration rates, turnover times and concentrations. Mar. Ecol. Prog. Ser. 70: 189-199

Torrella, F., Morita, R. X. (1979). Evidence for a high incidence of bacteriophage particles in the waters of Yaquina Bay, Oregon: ecological and taxonomical implications. Appl. environ. Microbiol. 37: 774-778

Van Etten, J. L., Burbank, D. E., Xia, Y., Meints, R. H. (1983). Growth cycle of a virus, PBCV-1 that infects Chlorella-like algae. Virology 126: 117-125

Waters. R. E., Chan, A. T (1982), Micromonas pusilla virus: the virus growth cycle and associated physiological events within the host cells; host range mutation. J. gen. Virol. 63: 199-206

Manuscript first received: May 29, 1992

Revised version accepted: Augusi 24, 1992 